\title{
Subprime Mortgage Delinquency and Default Rates by Metropolitan Area: An Analysis by Origination Vintages and Projections for 2007
}

\author{
Gerald A. Hanweck* \\ Professor of Finance, School of Management, George Mason University \\ *Corresponding author: ghanweck@gmu.edu \\ Received January 22, 2014; Revised Month February 19, 2014; Accepted February 20, 2014
}

\begin{abstract}
Subprime mortgage default rates have led to a crisis in the residential mortgage markets unprecedented since the Great Depression. Information reported on these defaults has demonstrated that they vary by location and region. To properly understand the causes of such high rates of mortgage defaults, we undertook this study. It reports on a cross-section analysis of default rates of residential, subprime and Alt-A mortgages aggregated to the metropolitan areas (MSA) level. The hypotheses tested here represent the effects of loan and borrower level characteristics and MSA economic factors, such as MSA employment growth, unemployment rate, household income and housing price changes and their volatility on the level of default rates on subprime mortgages. We test these by origination vintage for 2005 and 2006 and project default rates by MSA into 2007 using 2006 vintage estimated parameters. We find that loan and borrower level characteristics such as loan-to-value ratio weighted by original loan balances, the weighted proportion of loans that have no documentation or the borrowers' weighted FICO score and MSA economic factors of housing price changes and employment growth are highly statistically significant and economically important in explaining MSA subpirme residential mortgage default rates over the 359 MSAs for 2005 and 2006 vintages. The data used are from Loan Performance data base for 6 million subprime loans separated into 2005 and 2006 vintages, the OFHEO (now FHFA) Housing Price Index and household employment Dept. of Labor. Projections of housing price changes and employment growth for each MSA were used based on a linear extrapolation of the past 9 months of 2006 and the first 3 months of 2007. The main finding is that the projected default rates for all of 2007 are larger than those of 2005 and 2006 on average.
\end{abstract}

Keywords: Modeling Residential Mortgage Defaults, Residential Mortgage Delinquencies, subprime mortgages, Housing Market Collapse, Metropolitan Area Mortgage Markets

Cite This Article: Gerald A. Hanweck, "Subprime Mortgage Delinquency and Default Rates by Metropolitan Area: An Analysis by Origination Vintages and Projections for 2007." Journal of Finance and Economics, vol. 2, no. 1 (2014): 24-35. doi: 10.12691/jfe-2-1-4.

\section{Introduction}

By mid-March 2007, the subprime mortgage market in the U.S. had virtually collapsed. Many subprime monoline firms have either been sold or are in bankruptcy. Further evidence of this collapse is that the ABX-HE-BBB index, an index represented by a basket of 20 credit default swaps referencing U.S. subprime home equity securities of rating BBB, has declined from 100.1 on September 12, 2006 to 76.8 by mid- March and down to 26 by November 2007. This represents a 74 percent increase in the cost of a CDS, equivalently the cost of default insurance, on these securities. This study looks at the causes of this collapse in terms of the default experience of subprime mortgages on an MSA basis. It is recognized that not all subprime loans will default and so the study attempts to develop proxies of loan and borrower factors that indicate those loans most likely to default given that characteristics of the MSA housing market. Consideration of the MSA characteristics is an attempt to address the question why there are so many defaults during a period of no recession and a high rate of employment? To do this it is recognized that borrowers' willingness to pay depends largely on their desire to be a home owner rather than an investor in a residential property. To capture this desire, variables from the Loan Performance data base on loan and borrower characteristics at the rime of loan origination will be used.

The study will develop a model of individual mortgage debt valuation and to use this model as a guide for empirical estimation and choice of variables explaining default with data based subprime mortgages from the Loan Performance database. The value of the securitization of individual mortgage loans depends on the values of the mortgages in the pool. Once these models are estimated, the implied likelihood of default for the aggregate of mortgages in an MSA can be computed and projections can be made of the rate of default in an MSA given the MSA characteristics. Our hypothesis is that the likelihood of default of the loans originated in 2003 or 2004 were 
statistically much less than would have been estimated using a default model based on recent experience and much less than the current default frequency of 13 percent to 17 percent of subprime loans originated in 2005 and 2006, respectively. As suggested by anecdotal information, the progressively lax underwriting standards are likely to be the main cause of progressively larger rates of default by origination vintage and are proxied by low borrower FICO scores at origination, low borrower income to interest and principal payments after the expiration of low initial interest rates charged, rising loan-to-value ratios as housing prices sagged in 2006-2007 and increasing uncertainty or volatility of housing prices.

This paper reports on a cross-section analysis of default rates of residential, subprime mortgages aggregated to the metropolitan areas (MSA) level. As described below, the hypotheses tested represent the effects of loan and borrower level characteristics and MSA economic factors, such as MSA employment growth, unemployment rate, household income and housing price changes and their volatility on the level of default rates on subprime mortgages. In summary, we find that loan and borrower level characteristics such as loan-to-value ratio weighted by original loan balances, the weighted proportion of loans that have no documentation or the borrowers' weighted FICO score are highly statistically significant and economically important in explaining MSA loan default rates over the 359 MSAs for 2005 and 2006 vintages (Table 2 and Table 3).

In addition, the estimated models for the 2006 vintage are used to project each MSA default rate for the 2007 vintage for the entire year. Here we use projections of housing price changes and employment growth for each MSA based on a linear extrapolation of the past 9 months of 2006 and the first 3 months of 2007. We find that the projected default rates for the 2007 vintage are larger than those of 2005 and 2006 on average. However, for those MSAs with the greatest projected housing price declines, their default rates are greater than from the 2006 vintage and are the highest for all MSAs. Since housing price declines have become even more severe in 2007 than in the latter part of 2006, the rate of default will likely be higher than our projections suggest. To test this we decreased the housing price year-over-year rate of change by 1 percentage point and found that on average this would increase default rates by 3 percentage points. This is an economically and statistically meaningful increase and translates into an average percentage increase in the default rates of between 13 and 17 percent. This confirms that an increase in the severity of the housing price decline, which worsened in the summer and fall of 2007, will have a substantial increase in default rates and a serious decline in the possible recoveries from these defaults in 2007 and 2008 and possibly extending to 2009 .

\section{Valuation of Default Risky Debt}

The model that we use is that of Merton (1974) and Black and Cox (1973), MBC, to value corporate debt and its derived risk neutral probability of default. In our study this model is employed to value the mortgage debt, with the real estate property being the underlying asset in the option, and derive the risk neutral probability of insolvency or default. In this regard, we follow the application of the MBC model to residential mortgages as developed by Hendershott and Van Order (1987) and Giliberto and Ling (1992), and a similar model for commercial mortgages by Titman and Torous (1989).

In general, the value of default risky debt can be thought of as the present value of the cash flow stream of the debt if it were default risk free less the value of an option held by the borrower to put the underlying asset to the lender if the borrower can not or is unwilling to continue paying off the debt. If this happens the borrower defaults on the debt obligation. As developed, the likelihood of this occurring increases as the value of the underlying property falls toward or below the value of the debt owed by the borrower.

Let $\mathrm{Lt}_{\mathrm{t}}$ be the value of risky debt at time $\mathrm{t}$ and is defined for a zero coupon debt as:

$$
L_{t}=B \exp (-R \tau)=B \exp \left(-R_{f} \tau\right)-p_{t}
$$

where, $R(\tau)$ is the default risky discount rate, $R_{f}(\tau)$ is the risk free discount rate, $\operatorname{Bexp}(-\mathrm{R} \tau)$ is the present value of the default risky debt, $\mathrm{Be}\left(-\mathrm{R}_{\mathrm{f}} \tau\right)$ is the present value of the debt without any default risk, $\tau$ is the time to maturity, and $\mathrm{p}_{\mathrm{t}}$ is the put option value that the lenders give the borrowers on the underlying asset at a strike price of the debt owed, B. In the MBC model the debt is considered to be zero coupon debt, an assumption that will be relaxed below when the model is applied to residential mortgages. In our case the underlying asset is the real estate placed as collateral on the loan and is valued at $\mathrm{V}_{\mathrm{t}}$.

The put option is the option held by the borrower to put the underlying property to the lender. In terms of the MBC continuous time model, the put option can be expressed as:

$$
p_{t}=B \exp \left(-R_{f} \tau\right) N\left(-d_{2}\right)-V_{t} N\left(-d_{1}\right)
$$

where:

$$
\begin{aligned}
& d_{1}=\left(\ln \left(V_{t} / B\right)+\left(R_{f}+0.5 \sigma_{V}^{2}\right) \tau\right) / \sigma_{V} \sqrt{\tau} \\
& \text { and } d_{2}=d_{1}-\sigma_{V} \sqrt{\tau}
\end{aligned}
$$

The value of the default risky mortgage debt can be restated by substitution of (2) into (1) and collecting terms:

$$
L_{t}=B \exp \left(-R_{f}\right) N\left(d_{2}\right)+V_{t} N\left(-d_{1}\right)_{2}
$$

From (4) and (3) the value of the default risky debt will increase as the value of the underlying property increases relative to the debt owed $\left(\mathrm{V}_{\mathrm{t}} / \mathrm{B}\right)$ and as the volatility of the underlying rate of change in the value of the property $(\sigma \mathrm{V})$ decreases (see (1) where the put option value will rise with the increase in property value volatility). In this model, borrower insolvency occurs when the value of the underlying asset falls below the promised value of the debt at any time. However, lesser housing price volatility can forestall this from occurring and can deter a borrower defaulting on the loan, i.e., giving over the property to the lender or entering into foreclosure.

\footnotetext{
${ }^{1}$ Note, the inverse of $\mathrm{V}_{\mathrm{t}} / \mathrm{B}$ is the traditional loan-to-value ratio, LTV at time $\mathrm{t}$.

${ }^{2} 1-\mathrm{N}\left(-\mathrm{d}_{2}\right)$ is $\mathrm{N}\left(\mathrm{d}_{2}\right)$.
} 


\subsection{Risk Neutral Probability of Default of Default Risky Borrowers}

In the MBC model, the risk neutral probability of default is given by $\mathrm{N}\left(-\mathrm{d}_{2}\right){ }^{3}$ More specifically from (3):

$$
d_{2}=\left(\ln \left(V_{t}\right)-\ln (B)+\left(R_{f}-0.5 \sigma_{V}^{2}\right) \tau\right) / \sigma_{V} \sqrt{\tau}
$$

Hull points out that this value is also the number of standard deviations that the underlying asset value must change for it to fall below $\mathrm{B}$ and trigger a default. ${ }^{4}$ The smaller is $d_{2}$, the more likely the borrower is to default. By assuming that the $\mathrm{V}$ is lognormally distributed, as above, the risk neutral probability of insolvency or, in the terminology of Moody's KMV, of default is:

$$
N\left(-d_{2}\right)=N\left[\left(\ln \left(B / V_{t}\right)-\left(R_{f}-0.5 \sigma_{V}{ }^{2}\right) \tau\right) / \sigma_{V} \sqrt{\tau}\right]
$$

This simple model identifies the principal factors in the valuation of default risky debt and the risk neutral likelihood of default. These are $\mathrm{B} / \mathrm{V}_{\mathrm{t}}$ (the loan-to-value ratio), $\sigma \mathrm{V}$, asset volatility, and $\tau$, the time to expiration which could be considered the holding period of the borrower, the level of interest rates relative to the existing coupon rate on the mortgage, and/or time to interest rate reset for adjustable rate mortgages (ARMs). However some of these factors are not fully identified. For example, any impairment of the ability of the borrower to pay the interest and principal can be considered to increase the uncertainty of the cash flow from the borrower and the asset value accordingly. However, if the market value of the real estate exceeds what is owed on the debt, the borrower can simply sell the property and payoff the loan. The borrower does not default and the lender is made whole just as in any mortgage prepayment. Thus, the inability of the borrower to pay on the mortgage is an important factor in possible default only when the value of the property falls to near or below the value of the outstanding debt (i.e., the optionality of the model). This suggests that loan defaults are going to be most affected by falling housing prices and rising loan-to-value ratios (falling $\mathrm{V}_{\mathrm{t}} / \mathrm{B}$ and rising $\ln (\mathrm{B})-\ln \left(\mathrm{V}_{\mathrm{t}}\right)$ ) than by factors that affect households' ability to repay, such as declining employment or rising unemployment. We will explore economic and demographic factors more when the empirical default model is specified at the metropolitan area level.

\subsection{Interpretation and Relaxation of the Assumptions of the MBC Model Parameters}

\subsubsection{The Value of Debt Owed, B}

The value of the debt outstanding, $\mathrm{B}_{t}$, needs a more precise definition in the application of the MBC model to value mortgages. In the MBC model as initially developed, debt was considered to be a zero coupon bond with a single maturity date with the option exercise only at the due date of the debt - either it was repaid, renewed or

\footnotetext{
${ }^{3}$ Hull (2007) p. 270-272 and Hull (2000) p. 630-632.

${ }^{4}$ This value is also known as the distance to default as used by Moody's KMV.
}

defaulted and the asset put to the lenders. In contrast, a mortgage consists of a cash flow where, normally, principal and interest are paid monthly based on either a fixed or adjustable rate. ${ }^{5}$ For fixed rate mortgages, the payments stream represents an annuity until the maturity of the mortgage, $\mathrm{T}$, and with prepayment and default options. The certain payment value if the mortgage pays to maturity is the discounted values of these cash flows discounted by the risk-free rate for a term equal to the remaining maturity. However, if the house is sold or refinanced, the amount of the debt owed is the outstanding principle plus accrued interest. Thus if a borrower defaults, the value of the mortgage that is owed is the outstanding principal, the same as would be paid off if the borrower refinanced the mortgage. For the mortgage model, then, it is this value that we assign to $\mathrm{B}_{\mathrm{t}}$ for each month, $\mathrm{t}$, since payments of principal are made along with interest. An exception to this approach is for mortgages with an interest-only period. In this case $\mathrm{B}$ either remains constant over this period or increases it is a negative amortization loan. In either case, $\mathrm{B}$ will change in a defined and systematic way with time.

From a different perspective, the borrower is committed to paying each period a contracted amount of interest and principal. This amount is considerably less than the outstanding principal. If the borrower can not meet these obligations, the loan is considered delinquent and the lender can declare it in default (usually not sooner than 90 days in delinquency). At this stage, the lender can file to repossess the property and put it up for sale or hold in REO. So that the obligation committed to by the borrower to make monthly payments encourages them to evaluate the value of the property to them relative to what they owe on the mortgage, $\mathrm{B}_{\mathrm{t}}$, or the outstanding balance. So the value of the outstanding balance of the debt is considered as the strike price of the put option in (1) and (2) above.

\subsubsection{Home Owner's Housing Consumption Value and Psychic Income from Ownership}

Influencing the choice of when to put the property back to the lender if the market value of the property is less than the debt value as defined above, is the willingness of the borrower to make the mortgage payments. A borrower has an incentive to pay the mortgage because the household gets a consumption value from residing in the house over and above the market value of the property. This periodic consumption value needs to be added to the market value of the house at each period in the life of the loan. ${ }^{6}$ This adjustment has no effect on the likelihood of prepayment for refinancing or its timing, but does effect how far property values must decline to trigger default: asset values must fall below psychic value derived from home ownership plus the outstanding debt value. We treat this factor as more than simply an implied rental rate since it includes the value to the borrower of homeownership. In our empirical analysis, we will try to capture this psychic

\footnotetext{
${ }^{5}$ ARM contracts can be of an overwhelming variety with such features as interest only, negative amortization or teaser rates interest only. In the empirical estimation we will try to account for these differences with information about the payment type for the mortgages from Loan Performance data.

${ }^{6}$ Hendershott and Van Order (1987, p.40) term the consumption value a service flow and treat it as a dividend in their mortgage default model. We will treat this consumption value as an addition to asset value when considering default.
} 
income from homeownership and the ability of the borrower to pay the mortgage by a variable that measures the presence (or absence) of loan documentation. The reasoning for this variable will be discussed more fully in the empirical section below.

The effect of including the psychic income from the ownership of the house is to account for the fact that many borrowers will continue to pay on a mortgage when the market value of the property is less that what is owed on the mortgage. In a reasonably competitive housing market, homeowners could give over their home to the lender when the market value is less than the debt owed and rent a similar property, allowing them to get the same consumption value. If they do not and assuming rationality on the part of homeowners, the psychic value from homeownership is positive. This means that the rational mortgage borrower will be willing, if they have the sufficient resources, to continue in what would be an unfavorable out-of-the-money mortgage. It also helps explain those borrowers', with little or no homeownership pride, willingness to default as soon as the market value of the property can be reasonably expected to fall below the amount of the debt owed. The implication is that borrowers acquiring property for investment purposes would either try to sell the property quickly or default more often as property values fall. We will argue below that the absence of loan documentation, if the house is expected to be owner occupied, or whether the house is a single family detached or townhouse are important factors in helping to account for these types of borrowers.

Based on this discussion, we assume that borrowers will set a threshold on the market value of the property such that if it is less than the threshold the borrower will give over the property to the lender. The threshold property market value, $\mathrm{V}^{*}$, will encompass the psychic income from ownership, PSI, and the value of the debt owed. The threshold can be stated as:

$$
V_{t}^{*}=B_{t}-P S I_{t}
$$

This suggests that mortgages that were originated say one year before a housing price peak, would have to experience greater declines in housing values from the peak before defaulting than for mortgages originated at or near the peak because for a similar property with the same LTV since it has higher debt value, but the same PSI. This helps explain why mortgages originated at or near a housing peak may default more rapidly as housing prices fall than mortgages originated one year prior to the peak when housing prices were still rising. Explicit recognition of psychic income of home ownership also helps confirm that as a long as the borrower has sufficient cash flow, those with greater psychic income will require greater housing price declines than a those with little or no attachment to the property except as an investment before defaulting.

\subsubsection{Other Factors Influencing Mortgage Default}

Other factors are thought to be important in determining default on a mortgage. Bartlett (1994) specifies the following list:

1. Borrower employment status,

2. Loan purpose such as a mortgage for purchase of the property of a refinance,
3. Property type such as single-family detached, townhouse or condominium,

4. Loan type such as a 30-year fixed rate mortgage or an ARM or reduced payment loan,

5. Loan seasoning,

6. Absolute loan size with large loans being associated with properties with greater value variability,

7. Loan documentation ranging from full documentation to no documentation indicates the quality of the underwriting, and

8. Presence of a second mortgage.

Empirical proxies for these factors in many cases are present in the Loan Performance database that we use and from demographic data for MSAs (Table 1 shows the variables used in the study).

Following Demyanyk and Van Hemert (2007), “there is a large literature studying the determinants of mortgage delinquencies and foreclosures, dating back to at least von Furstenberg and Green (1974)." Two of the more recent studies include Cutts and van Order (2005) and Pennington-Cross and Chomsisengphet (2007). ${ }^{7}$ To the best of our knowledge, we are the first to study the effects of a number of determinants contributing to the high delinquency and foreclosure rates for 2005 and 2006 vintage subprime mortgages by MSA. To this end, we find a trend in the delinquency and foreclosure rate from 2005 to 2007 vintage mortgages, accounting for different loan characteristics, borrower characteristics, house price appreciation and employment growth. This is consistent with the trend found by Demyanyk and Van Hemert (2007) for 2001 to 2006 vintages using the Loan Performance data. They also found that 2006 vintage loans had the highest rate of delinquency and foreclosure of any other vintage at ages up to 16 months with 2005 vintages in second place. Finally, we project default rates to 2007 using reported 2007 delinquencies and foreclosures and changes in other factors using the 2006 vintage parameter estimates.

\section{Data Sources, Variables and Empirical Estimation}

\subsection{Empirical Model}

The model used for estimation relates measures of subprime loan default rates, as defined below, to characteristics of the loan and associated borrower and economic characteristics of the metropolitan area. Formally the model is:

$$
\text { DefaultRate }=\mathrm{f}\left(\begin{array}{l}
\text { loan characteristics, } \\
\text { borrowercharacteristics, } \\
\text { MSA economiccharacteristics }
\end{array}\right)
$$

Since the default rate will take on values between 0 and 1 , the estimating procedure should take this into consideration. One method used to do this is the Tobit procedure which assumes that the dependent variable can take on any value between 0 and 1 and that there is an index variable that is normally distributed. Even though our

\footnotetext{
${ }^{7}$ Deng, Quigley, and Van Order (2000) discuss the simultaneity of the mortgage prepayment and default option. Campbell and Cocco (2003) and Van Hemert (2007) discuss mortgage choice over the life cycle.
} 
data could have any value within the assumed range, there are no values for any MSA or vintage at or near the lower or upper bounds. Estimating our model with Tobit regression gives identical estimated parameters as does linear regression. Based on this result we only report the linear regression estimates.

Table 1. Variable Definitions and Univariate Descriptive Statistics

\begin{tabular}{|c|c|c|c|c|c|}
\hline Variable Names & Variable Definition & $\begin{array}{c}\text { Mean } \\
2005 \\
\end{array}$ & $\begin{array}{l}\text { Stdev. } \\
2005\end{array}$ & $\begin{array}{c}\text { Mean } \\
2006\end{array}$ & $\begin{array}{c}\text { Stdev. } \\
2006\end{array}$ \\
\hline \multicolumn{6}{|l|}{ Default Rates } \\
\hline dfw60p & $\begin{array}{l}\text { Variable is } 60 \text { days or more delinquent, in foreclosure, bankruptcy or } \\
\text { REO. }\end{array}$ & 0.1266 & 0.0444 & 0.1692 & 0.0420 \\
\hline dfw90p & $\begin{array}{l}\text { Variable is } 90 \text { days or more delinquent, in foreclosure, bankruptcy or } \\
\text { REO. }\end{array}$ & 0.0768 & 0.0344 & 0.1053 & 0.0335 \\
\hline \multicolumn{6}{|l|}{ Loan Characteristics } \\
\hline wtd_ltv & $\begin{array}{l}\text { Loan LTV ratios weighted by outstanding balance ratio of the mortgage } \\
\text { at origination to the total origination balance in the MSA }\end{array}$ & 84.160 & 2.5685 & 84.473 & 2.8700 \\
\hline wtd_fico & $\begin{array}{c}\text { FICO scores weighted by outstanding balance ratio of the mortgage at } \\
\text { origination to the total origination balance in the MSA }\end{array}$ & 620.36 & 10.055 & 620.11 & 9.7091 \\
\hline proparm & $\begin{array}{l}\text { Proportion of loans that are ARM weighted by outstanding balance ratio } \\
\text { of the mortgage at origination to the total origination balance in the } \\
\text { MSA }\end{array}$ & 0.7359 & 0.0739 & 0.6852 & 0.0724 \\
\hline propdoc & $\begin{array}{c}\text { Proportion of loans that have no documentation weighted by } \\
\text { outstanding balance ratio of the mortgage at origination to the total } \\
\text { origination balance } \\
\text { in the MSA }\end{array}$ & 0.2967 & 0.1007 & 0.3126 & 0.1080 \\
\hline propfirst & $\begin{array}{l}\text { Proportion of loans that are first mortgages weighted by outstanding } \\
\text { balance ratio of the mortgage at origination to the total origination } \\
\text { balance in the MSA }\end{array}$ & 0.9429 & 0.0193 & 0.8992 & 0.0331 \\
\hline propoccup & $\begin{array}{l}\text { Proportion of loans where borrowers declare they will occupy the house } \\
\text { weighted by outstanding balance ratio of the mortgage at origination to } \\
\text { the total origination balance in the MSA }\end{array}$ & 0.9278 & 0.0388 & 0.9277 & 0.0354 \\
\hline propprtype & $\begin{array}{l}\text { Proportion of loans where the house is a single family detached or } \\
\text { townhouse home weighted by outstanding balance ratio of the mortgage } \\
\text { at origination to the total origination balance in the MSA }\end{array}$ & 0.8702 & 0.1896 & 0.8737 & 0.1122 \\
\hline proppurpose & $\begin{array}{c}\text { Proportion of loans where the loan is to purchase the property weighted } \\
\text { by outstanding balance ratio of the mortgage at origination to the total } \\
\text { origination balance in the MSA }\end{array}$ & 0.5102 & 0.0897 & 0.5151 & 0.0993 \\
\hline propinitrt & Initial interest rate (\%) & 7.8561 & 0.3568 & 8.8198 & 0.3718 \\
\hline \multicolumn{6}{|l|}{$\begin{array}{c}\text { Market } \\
\text { Characteristics }\end{array}$} \\
\hline emp_ratio & $\begin{array}{l}\text { Year-over-year growth in employment for } \\
\text { the MSA }\end{array}$ & 0.0173 & 0.0278 & 0.0165 & 0.0210 \\
\hline hpi_ratio* & $\begin{array}{l}\text { Year-over-year proportional changes in OFHEO housing prices for the } \\
\text { MSA }\end{array}$ & 0.1124 & 0.0800 & 0.0501 & 0.0482 \\
\hline hpi_ratio_std** & $\begin{array}{l}\begin{array}{l}\text { Standard deviation of housing price changes by MSA for the past } 12 \\
\text { months }\end{array} \\
\end{array}$ & 0.0382 & 0.0342 & 0.0280 & 0.0244 \\
\hline msaempsize & $\begin{array}{l}\text { Size of the MSA measured by the natural } \\
\text { logarithm of total MSA employment }\end{array}$ & 11.539 & 1.7013 & 11.561 & 1.6952 \\
\hline
\end{tabular}

* Probability of less than zero for hpi_ratio assuming this variable is distributed as a normal pdf:

2005: 0.0799 and 2006: 0.1495. Thus, it is almost twice as likely to have a MSA with a housing price decline in 2006 as in $2005 . * *$ Using these data the risk neutral probability of default, equation (6), is less than 0.00001 for 2005 and 2006 at the mean values of wtd_ltv, hpi_ratio_std and risk free rates of 4.6 percent for a 10 -year T-Bond rate.

\subsection{Data Sources and Variable Definitions}

\subsubsection{Loan and Borrower Characteristics}

The data for the loan and borrower characteristics are from the Loan Performance database. This database has some 14 million subprime loans that have been sold into securitizations at various times since 2001. We use data for 8 million loans separated into 2005 and 2006 origination vintages. These origination dates were chosen because they constitute the period of the boom in originations and housing prices during 2005 and the period where housing prices were slowing or, for some MSAs, peaked, in 2006. The data from this source are aggregated by MSA using the information on the Zip Code of the borrower available from Loan Performance. Zip Codes were matched with a file containing the Zip Codes and CBSA codes from the Census Department. ${ }^{8}$ These data

\footnotetext{
${ }^{8}$ The term CBSA refers to "core based statistical area" that became effective in 2000 and refers collectively to metropolitan and micropolitan statistical areas (see

http://www.census.gov/population/www/estimates/aboutmetro.html).
}

were then matched with data from the U.S. Labor Department containing MSA codes that were then used to identify metropolitan areas for matching with household employment data and the housing price index data from the Office of Federal Housing Enterprise Oversight, OFHEO.

Two default rate proxies are used (see Table 1). ${ }^{9}$ The first is for loans designated as "60 days or more delinquent, in foreclosure, bankruptcy or REO” at anytime in the years 2005 and 2006. These are designated by as $d f w 60 p$. The second default proxy is $d f w 90 p$ defined as loans " 90 days or more delinquent, in foreclosure, bankruptcy or REO” at anytime in the years 2005 and $2006 .{ }^{10}$ For each of these variables, loans that have been prepaid are ignored and not counted in the analysis. Since precisely specifying when a loan is in default is difficult and not specified in the Loan Performance database, these proxies are the best measures

\footnotetext{
${ }^{9}$ For our study Alt A loans are included in the definition of subprime loans.

10 These are defined in the Loan Performance database and described in “TrueStandings Securities: Attributes Metrics and Filters," (2005), Loan Performance.
} 
of the state of non-payment of principal and interest indicating that the borrower will not recover to make payments in arrears. Each of these variables is measured as a weighted proportion to total MSA original loan value of each of the default states for each vintage.

The loan and borrower characteristic variables that we use attempt to follow those discussed above as likely indicators of default. The loan-to-value ratio at origination is reported at the loan level in the Loan Performance database (Table 1). This variable is designated as wtd_ltv. For each loan, the value of the original loan balance is divided by the appraised value or reported appraised value of the property on which the loan is made. The appraised value is as reported by the originator and may be subject to error. The loan balance that is used is the mortgage balance including any second mortgages or any take-downs on home equity lines of credit made at the time of origination. To form the MSA-level variable, each loan is weighted by its proportion of the total original loan values of subprime loans to borrowers in the MSA and then aggregated. ${ }^{11} \mathrm{We}$ expect that, following the model above in equation (6), a greater LTV will lead to a greater rate of default because the collateral is more highly leveraged.

To capture the credit quality of the borrower, the FICO score is used and reported by the lender. At the MSA level this variable is designated as wtd_fico and is the origination weighted loan amount of individual FICO scores. We expect that the higher the FICO score, the better the credit quality of the borrower and the less the likelihood of default.

The structure of the mortgage is captured by the whether it is an ARM or not. At the MSA level, the loan amount weighted proportion of loans that are ARMs is designated as proparm. Our hypothesis is that the greater the proportion that are ARMs the more likely the mortgages are to default because the rates will usually reset much higher for subprime loans and the greater the servicing burden the borrower will have to bare.

The discussion above with regard to the psychic income from homeownership is proxied by the type of documentation the borrower was required to supply and whether the house is intended to be owner occupied. Borrowers that supplied little documentation and did not intend to live in the house were likely those willing to sell the house as soon as it became profitable and had little psychic attachment to the property. The hypothesis is that borrowers are more likely to default if they supplied little or no documentation and did not intend to be occupants. These variables are designated as propdoc and propoccup, respectively. One other variable that may serve as a proxy for homeowner attachment to the property is whether the loan is for purchase of the house or a refinancing. This variable is designated as proppurpose and is expected to indicate lesser likelihood of default the greater the proportion of loans are for purchases.

Another variable that can provide some indication of credit quality is whether the loan is a first lien or other. This variable is designated as propfirst and we expect that the greater this proportion, the lower the default rate.

We also attempt to control for the type of property (propprtype) - single family detached or townhouse

\footnotetext{
${ }^{11}$ This procedure is followed for all of the loan and borrower level characteristics.
}

compared to others such as condominiums - and the initial rate of interest, actually the coupon, on the mortgage (propinitrt). We expect that if the property is a single family detached or a townhouse that the likelihood of default over the sample period is less because of the greater resources initially required to own one of these properties compared to a condominium. The initial interest rate variable may have two interpretations. The higher the rate the greater the risk of default expected by the lender. From this interpretation, high rates indicate riskier loans that should lead to higher defaults. An alternative interpretation is that a higher initial rate means that the borrower is not getting a teaser that will adjust later on and the lender and borrower are more confident that the borrower can make the payments at the high rate. This interpretation implies that higher rates are associated with borrowers that are able to make payments and have a lesser likelihood of defaulting.

\subsubsection{Economic Characteristics of the MSA}

Economic factors influencing default rates are captured by the year-over-year rate of household employment growth, emp_ratio, and the year-over-year proportional changes in the median house price, hpi_ratio, at the MSA level. The employment data by MSA are from the U.S. Labor Department and the housing price data are from the quarterly OFHEO housing price survey. Both of these series are reported in Haver Analytics, Inc. by metropolitan area. Employment growth is a proxy for the ability of households to earn and make payments on their debt. The housing price appreciation/depreciation rate is a proxy for the rate of accumulation or loss of equity in the home and as an indicator of sale or refinance ability of the property. We expect that the higher is employment growth or housing price changes, the less the rate of default in the MSA.

Two other variables were used to capture metropolitan area economic conditions. The volatility of the housing price changes over the past 12 months, as measured by the standard deviation of the proportional change in median house prices, is designated as hpi_ratio_std. We expect, following the model of risk neutral probability in (6), that the greater the volatility of housing price changes, the greater will be rates of default. Essentially, the value of the option to put the property to the lender increases with volatility, lowering the debt market value and increasing the likelihood of default.

The other measure is the size of the MSA measured by the natural logarithm of the total MSA employment at the end of each year. We expect that larger MSAs may have more competitive housing markets with more alternatives for home buyers so that defaults would be less likely since home buyers would be able to more readily find alternative rental housing similar to the house they desired to own.

\subsection{Empirical Results}

Table 1 includes the definitions of all the variables and descriptive statistics for each used in the analysis for each of the mortgage origination vintages for 2005 and 2006. As expected, rates of default increased from the 2005 vintage to the 2006 vintage for both measures of default rate. The increase in the mean MSA default rates, from 0.1266 to 0.1692 for dfw60p and 0.0768 to 0.1053 for dfw90p, are 
large enough increases to be statistically significant with 359 observations (t-values on the order of 18). As we will see from the model projections for the full year of 2007, this increased trend of rates of default by MSA is persisting.

Other loan characteristics experiencing significant change are proparm, propdoc, propfirst and propinitrt. The decline in proparm suggests that 2006 has less pressure for defaults and the decline in propfirst indicates more pressure for defaults. Similarly, propdoc increased, indicating that there is greater pressure for higher rates of default for 2006 vintage subprime loans. In contrast, the level of the initial interest rate on the loan, propinitrt, increased along with overall interest rates in the economy. For example, the 10-year Treasury bond rate went up nearly 100 basis points on average from 2005 to 2006 .
The important market characteristic variable to show substantial change is the decline in the rate of housing price appreciation, hpi_ratio. This variable declined by more than half from 0.1124 to 0.0501 . This is very strong pressure for greater default rates in 2006 and is coincident with the observed increase of both dfw60p and dfw90p. As will be seen from the 2007 projections, the rate of housing appreciation is projected to further slow in 2007 leading to greater pressure for higher rates of subprime mortgage defaults at the MSA level. As a precursor of future likelihood of price declines, the probability of hpi_ratio being less than zero, assuming this variable is distributed as a normal pdf, is 0.0799 for 2005 and 0.1495 for 2006 . Thus, it almost twice as likely to have a MSA with a housing price decline in 2006 as in 2005. If this continues, the likelihood of housing price declines might get above 20 percent for a substantial number of MSAs.

Table 2. Default Model Results for 2005 Vintage Subprime Loans

Panel 1: dfw60p

\begin{tabular}{|c|c|c|c|}
\hline \multicolumn{4}{|c|}{$\begin{array}{l}\text { Dependent Variable is } 60 \text { days or more delinquent, in foreclosure, bankruptcy or REO. } \\
\text { Linear Regression for } 2005 \text { vintage subprime loans by MSA. (*** significant at } 1 \text { percent or better, } \\
* * \text { significant at } 5 \text { percent and }{ }^{*} \text { significant at } 10 \text { percent for a one-tailed test). Dependent Variable: dfw60p }\end{array}$} \\
\hline Independent Variables & Coefficients & t-statistic & Sig. Level \\
\hline \multicolumn{4}{|l|}{ Loan Characteristics } \\
\hline wtd_ltv & 0.00602 & 3.82 & $* * *$ \\
\hline wtd_fico & -0.00292 & -7.23 & $* * *$ \\
\hline proparm & 0.06269 & 2.12 & $* *$ \\
\hline propdoc & 0.12986 & 3.41 & $* * *$ \\
\hline propfirst & 0.05164 & 0.36 & \\
\hline propoccup & -0.12984 & -2.40 & $* * *$ \\
\hline propprtype & 0.00721 & 0.35 & \\
\hline proppurpose & 0.07919 & 2.76 & $* * *$ \\
\hline propinitrt & -0.02694 & -2.42 & $* * *$ \\
\hline emp_ratio & -0.77846 & -11.87 & $* * *$ \\
\hline hpi_ratio & -0.10877 & -2.85 & $* * *$ \\
\hline hpi_ratio_std & 0.24402 & 2.32 & $* *$ \\
\hline msaempsize & 0.00038572 & 0.37 & \\
\hline Adj $\mathrm{R}^{2}$ & $\mathrm{~N}=359$ & $F=29.99$ & $* * *$ \\
\hline
\end{tabular}

Panel 2: dfw90p

\begin{tabular}{|c|c|c|c|}
\hline \multicolumn{4}{|c|}{$\begin{array}{l}\text { Dependent Variable is } 90 \text { days or more delinquent, in foreclosure, bankruptcy or REO. } \\
\text { Linear Regression for } 2005 \text { vintage subprime loans by MSA. (*** significant at } 1 \text { percent or better, } \\
* * \text { significant at } 5 \text { percent and * significant at } 10 \text { percent for a one-tailed test). Dependent Variable: dfw90p }\end{array}$} \\
\hline Independent Variables & Coefficients & t-statistic & Sig. Level \\
\hline \multicolumn{4}{|l|}{ Loan Characteristics } \\
\hline wtd_ltv & 0.00508 & 3.89 & $* * *$ \\
\hline wtd_fico & -0.00187 & -5.58 & $* * *$ \\
\hline proparm & 0.04245 & 1.73 & $*$ \\
\hline propdoc & 0.09139 & 2.89 & $* * *$ \\
\hline propfirst & 0.00122 & 0.01 & \\
\hline propoccup & -0.11049 & -2.46 & $* * *$ \\
\hline propprtype & 0.00753 & 0.44 & \\
\hline proppurpose & 0.04185 & 1.76 & $*$ \\
\hline propinitrt & -0.01875 & -2.03 & $* *$ \\
\hline emp_ratio & -0.62700 & -11.52 & $* * *$ \\
\hline hpi_ratio & -0.07296 & -2.3 & $* *$ \\
\hline hpi_ratio_std & 0.19803 & 2.27 & $* *$ \\
\hline msaempsize & 0.00045 & 0.52 & \\
\hline Adj R $^{2} \quad 0.4418$ & $N=359$ & $F=22.86$ & $* * *$ \\
\hline
\end{tabular}


Table 3. Default Model Results for 2006 Vintage Subprime Loans Panel 1: dfw60p

\begin{tabular}{|c|c|c|c|}
\hline \multicolumn{4}{|c|}{$\begin{array}{l}\text { Dependent Variable is } 60 \text { days or more delinquent, in foreclosure, bankruptcy or REO. } \\
\text { Linear Regression for } 2006 \text { vintage subprime loans by MSA. (*** significant at } 1 \text { percent or better, } \\
\text { ** significant at } 5 \text { percent and * significant at } 10 \text { percent for a one-tailed test). Dependent Variable: dfw60p }\end{array}$} \\
\hline Independent Variables & Coefficients & t-statistic & Sig. Level \\
\hline Intercept & 1.67175 & 6.26 & $* * *$ \\
\hline \multicolumn{4}{|l|}{ Loan Characteristics } \\
\hline wtd_ltv & 0.01008 & 7.42 & $* * *$ \\
\hline wtd_fico & -0.00317 & -9.77 & $* * *$ \\
\hline proparm & 0.08317 & 3.36 & $* * *$ \\
\hline propdoc & 0.31791 & 10.3 & $* * *$ \\
\hline propfirst & -0.03135 & -0.52 & \\
\hline propoccup & -0.22114 & -4.82 & $* * *$ \\
\hline propprtype & 0.01954 & 1.33 & \\
\hline proppurpose & 0.01015 & 0.45 & \\
\hline propinitrt & -0.04165 & -4.91 & $* * *$ \\
\hline \multicolumn{4}{|l|}{ Market Characteristics } \\
\hline emp_ratio & -0.16510 & -2.16 & $* *$ \\
\hline hpi_ratio & -0.32807 & -10.21 & $* * *$ \\
\hline hpi_ratio_std & 0.02311 & 0.28 & \\
\hline msaempsize & 0.00038 & 0.45 & \\
\hline Adj $\mathrm{R}^{2} \quad 0.5941$ & $\mathrm{~N}=359$ & $\mathrm{~F}=41.42$ & $* * *$ \\
\hline
\end{tabular}

Panel 2: dfw90p

\begin{tabular}{|c|c|c|c|}
\hline $\begin{array}{r}\text { Depende } \\
\text { Linear Regress } \\
* * \text { significant at } 5 \mathrm{p}\end{array}$ & $\begin{array}{l}\text { more delinquen } \\
\text { rime loans by } 1 \\
\text { t } 10 \text { percent for }\end{array}$ & $\begin{array}{l}\text { bankruptcy } \\
\text { icant at } 1 \mathrm{pe} \\
\text {. Depender }\end{array}$ & \\
\hline Independent Variables & Coefficients & t-statistic & Sig. Level \\
\hline Intercept & 0.78166 & 3.62 & $* * *$ \\
\hline \multicolumn{4}{|l|}{ Loan Characteristics } \\
\hline wtd_ltv & 0.00808 & 7.37 & $* * *$ \\
\hline wtd_fico & -0.00181 & -6.90 & $* * *$ \\
\hline proparm & 0.07476 & 3.73 & $* * *$ \\
\hline propdoc & 0.22855 & 9.17 & $* * *$ \\
\hline propfirst & 0.02363 & 0.49 & \\
\hline propoccup & -0.17264 & -4.66 & $* * *$ \\
\hline propprtype & 0.01190 & 1.01 & \\
\hline proppurpose & 0.00862 & 0.48 & \\
\hline propinitrt & -0.03057 & -4.47 & $* * *$ \\
\hline \multicolumn{4}{|l|}{ Market Characteristics } \\
\hline emp_ratio & -0.11420 & -1.85 & $*$ \\
\hline hpi_ratio & -0.27276 & -10.51 & $* * *$ \\
\hline hpi_ratio_std & 0.05237 & 0.79 & \\
\hline msaempsize & 0.00067493 & 0.98 & \\
\hline Adj $R^{2} \quad 0.6052$ & $\mathrm{~N}=359$ & $F=43.33$ & $* * *$ \\
\hline
\end{tabular}

\section{Regression Results and 2007 Vintage Default Rate Projections}

\subsection{Regression Results}

In this section we present the regression results for the 2005 and 2006 vintages separately (Table 2 and Table 3). For purposes of clarification, a vintage is defined for the year the mortgage was originated. The regressions by vintage are for the default rates and loan characteristics defined for the period from origination to the latest reporting date for the Loan Performance data (August 2007 for this study). ${ }^{12}$ Estimating parameters by vintage allows for the testing of the hypothesis that the characteristics of loans and economic factors affecting loan defaults differ by

\footnotetext{
${ }^{12}$ Using this approach, loans that had been paid off for reasons other than default are not included in the outstanding mortgages as of each vintage.
}

the period of origination. This testing will be discussed in the presentation of the estimated parameters.

The regression results for the 2005 vintage are reported in Table 2 for the default rate proxies, $d f w 60 p$ (Panel 1) and $d f w 90 p$ (Panel 2). For the $d f w 60 p$ default rate proxy, all loan characteristic variables, with the exception of propfirst and propprtype, are statistically significant at better than the 1 percent level except proparm which is significant at the 5 percent level. Most important is that all significant variables are of the hypothesized signs, with the exception of proppurpose. In addition, they are economically significant as exemplified by a two standard deviation increase for wtd_ltv and wtd_fico increasing $d f w 60 p$ by 0.035 and decreasing $d f w 60 p$ by 0.060 , respectively. Based on a mean default rate of 0.1266 , these changes would be substantial and even 1 standard deviation changes in these explanatory variables would be substantial. A similar pattern is found for $d f w 90 p$ as shown in Table 2, Panel 2. 
For the market economic characteristic variables for the $d f w 60 p$ default rate proxy, employment growth, emp_ratio, is statistically significant at better than the 1 percent level. House price appreciation, hpi_ratio, and its standard deviation, hpi_ratio_std, were found to be statistically significant at the 1 percent and 5 percent level, respectively. As in the case of the loan characteristic variables, all the market level variables are of the hypothesized signs with the exception of the market size variable, msaempsize, which is also not statistically significant. A similar pattern is found for $d f w 90 p$ with smaller coefficients than estimated for $d f w 60 p$, very likely due to the smaller scale for this variable, on average. One exception for $d f w 90 p$ is that the coefficient for the hpi_ratio is statistically significant at only the 5 percent level and is not of particular economic significance.

The overall fit of the regressions is good for a crosssection of 359 observations with an adjusted $\mathrm{R}^{2}$ of 44.2 percent for $d f w 90 p$ and 51.2 percent for $d f w 60 p$. These fits are highly statistically significant for both regressions at well better than the 1 percent level.

The 2006 vintage regression estimates are presented in Table 3. For the $d f w 60 p$ default rate proxy (Panel 1), all loan characteristic variables are statistically significant at better than the 1 percent level except propfirst, propprtype and proppurpose which are insignificant. All significant variables are of the hypothesized signs. Compared to the 2005 vintage coefficients, these are slightly larger for wtd_ltv and wtd_fico. Furthermore, the 2006 vintage coefficients for proparm, propdoc, propoccup and propintirt are considerably larger implying that default rates of this vintage of subprime loans are more economically sensitive to these factors. For example, an increase in propdoc by 2 standard deviations would increase $d f w 60 p$ for the 2006 vintage by 0.06 whereas it would only increase $d f w 60 p$ by 0.025 for the 2005 vintage. These changes, measured as a percentage change of the mean default rate for each vintage, are about 1.8 times greater for 2006 compared to 2005.

The economic market characteristics for the 2006 vintage show a markedly different pattern than for the 2005 vintage. For 2006, only the housing price appreciation variable, hpi_ratio, and the employment growth variable, emp_ratio, are statistically significant and of the hypothesized sign, while the other two variables are not statistically significant. In contrast to 2005, hpi_ratio is considerably more economically meaningful than is the emp_ratio (hpi_ratio is more than 4 times greater, -0.328 compared to -0.073 and the emp_ratio is 4.7 times smaller, -0.165 compared to -0.778$)$. These results indicate that 2006 vintage default rates are more economically and statistically sensitive to housing price changes than 2005 vintage rates and that 2005 vintages are more sensitive to changes in employment growth. This result is consistent with the hypothesis proposed above that default rates for mortgages originated after, at or near the peak in housing prices, as occurred for number of MSAs in 2006 for our sample, would be more sensitive to housing price changes underlying the mortgage loan than employment factors affecting household incomes and capacity to make loan payments. 2005 vintage loan defaults, in contrast, would be more sensitive to employment changes since housing prices had yet reached or were near their peak for most MSAs in 2005.
For the 2006 vintage $d f w 90 p$ default proxy, a similar pattern for the loan characteristic estimates is apparent as for the $d f w 60 p$ variable and the overall fit is better for 2006 vintages, $\mathrm{R}^{2}$ of 59.4 percent for $d$ fw60p and 60.5 percent for $d f w 90 p$. Compared to the 2005 vintage parameter estimates, proparm is much greater, while propdoc is considerably greater. For this vintage, propfirst is not statistically significant and not of the hypothesized sign. These results confirm that the subprime mortgages made with ARMs and without documentation have a considerably greater likelihood of default than fixed rate mortgages and those made with disclosure of the financial condition of the borrower absolutely and compared to 2005 vintage.

The economic market characteristic variables estimates for $d f w 90 p$ are consistent with those for the $d f w 60 p$ default proxy. The housing price appreciation variable is the only important economically and statistically significant variable at the 1 percent level, while only emp_ratio is significant at the 10 percent level and of the hypothesized signs. However, the signs are consistent with those found for $d f w 60 p$. Compared to the 2005 results, the same implications hold: 2006 vintage subprime mortgage defaults are more sensitive to housing price changes than 2005 defaults and 2005 vintage subprime mortgage defaults are more sensitive to employment growth changes than 2006 vintage loans.

\subsection{Vintage Default Rate Projections}

One of the reasons for developing models of MSA level subprime loan default rates is to project future defaults to identify those areas that may be or have become more burdened with mortgage credit quality deterioration. The presumption is that banks in areas with considerable mortgage defaults will have made mortgages to borrowers residing in the area and thus face credit quality problems themselves and/or be operating in an area of possible economic slowdown.

This subsection discusses subprime mortgage loan default projections using loans originated in 2007, i.e. 2007 vintage loans, and using the 2006 vintage parameter estimates. The Loan Performance data available at the time of estimation is updated through August of 2007 and is used for these projections. For our projections we use these data for comparison, but have annualized the 2007 default rate data to make it comparable with the estimates for each vintage. In this adjustment, we took a conservative approach and assumed that loan defaults for the period from August through December would be at the same rate for each MSA as in the previous 8 months. To project the economic factors for 2007, we estimate the employment growth rates and housing price appreciation for each MSA. We do this using the actual data for 2007 reported through June 2007 and find the rate over the past 12 months as a year-over-year trend. The trend is used to project each rate of change forward to the end of 2007. One drawback to this approach is that the employment data and housing price data were not available through August 2007 so that the projections using these data are using data available only through June 2007. This suggests that we may have some projection bias compared to actual values based on past trends for a particular MSA, but given the trend it is 
more likely that home prices and employment growth may decline more than the projections.

The results for the overall fit of the projections are reasonably good for $d f w 60 p$. The mean square error for $d f w 60 p$ is larger than for $d f w 90 p$ (0.0085 compared to 0.0033 ) and the mean error is positive for $d f w 60 p$ and negative for $d f w 90 p$ at 0.0091 and -0.0231 , respectively.
The mean difference for $d f w 60 p$ is not statistically significantly different from zero. Based on a projected mean for $d f w 60 p$ of 0.1767 , the average error is only 5 percent. For $d f w 90 p$ with a mean projected rate of 0.1089 , the error is considerably greater at 20 percent. Thus, for the projections we will concentrate on $d f w 60 p$ projections, but report each by MSA.

Table 4. 2007 Projected Default Rates Using 2006 Vintage Subprime Model Estimates By Projected Defaults as Measured by dfw60p

\begin{tabular}{|c|c|c|c|c|c|c|}
\hline \multicolumn{2}{|r|}{ MSA Name } & $\begin{array}{c}2007 \\
\text { wtd_ltv }\end{array}$ & $\begin{array}{c}2007 \\
\text { wtd_fico }\end{array}$ & $\begin{array}{l}\text { Projected } \\
\text { hpi_ratio }\end{array}$ & $\begin{array}{c}\text { Projected } \\
\text { dfw60p }\end{array}$ & $\begin{array}{c}\text { Projected } \\
\text { dfw90p }\end{array}$ \\
\hline 1 & Ithaca, NY & 82.00 & 601.78 & -0.08621 & 0.26073 & 0.16330 \\
\hline 2 & Santa Rosa-Petaluma, CA & 83.34 & 630.96 & -0.05386 & 0.25740 & 0.17801 \\
\hline 3 & Barnstable Town, MA & 79.16 & 618.04 & -0.04211 & 0.25620 & 0.17163 \\
\hline 4 & Jackson, MI & 87.13 & 609.36 & -0.08516 & 0.25230 & 0.16112 \\
\hline 5 & Detroit-Livonia-Dearborn, MI (MSAD) & 89.52 & 625.09 & -0.01459 & 0.24387 & 0.16488 \\
\hline 6 & Worcester, MA & 85.12 & 623.41 & -0.11104 & 0.24373 & 0.16887 \\
\hline 7 & Santa Cruz-Watsonville, CA & 81.98 & 633.87 & -0.15443 & 0.24104 & 0.17488 \\
\hline 8 & Miami-Miami Beach-Kendall, FL (MSAD) & 83.53 & 625.93 & -0.01876 & 0.23899 & 0.16231 \\
\hline 9 & Cape Coral-Fort Myers, FL & 87.17 & 629.95 & -0.08012 & 0.23808 & 0.16595 \\
\hline 10 & Sarasota-Bradenton-Venice, FL & 82.59 & 619.32 & -0.04690 & 0.23307 & 0.15283 \\
\hline 11 & Atlantic City, NJ & 79.98 & 608.80 & 0.04768 & 0.22932 & 0.14168 \\
\hline 12 & Sebastian-Vero Beach, FL & 86.40 & 626.08 & 0.01528 & 0.22856 & 0.14762 \\
\hline 13 & Rockford, IL & 89.63 & 616.83 & 0.00470 & 0.22832 & 0.15121 \\
\hline 14 & Saginaw-Saginaw Township North, MI & 89.14 & 611.55 & -0.05845 & 0.22832 & 0.14921 \\
\hline 15 & Stockton, CA & 86.41 & 633.05 & -0.05382 & 0.22803 & 0.16231 \\
\hline 16 & Muskegon-North Shores, MI & 89.69 & 620.08 & -0.04223 & 0.22799 & 0.14589 \\
\hline 17 & Bismarck, ND & 89.02 & 615.37 & 0.01683 & 0.22690 & 0.14682 \\
\hline 18 & Port St. Lucie, FL & 84.99 & 618.97 & 0.03242 & 0.22457 & 0.14372 \\
\hline 19 & Punta Gorda, FL & 82.51 & 618.91 & -0.04792 & 0.22184 & 0.14362 \\
\hline 20 & Naples-Marco Island, FL & 81.91 & 628.69 & -0.02171 & 0.22161 & 0.14880 \\
\hline 21 & Panama City-Lynn Haven, FL & 83.79 & 620.79 & -0.07842 & 0.22146 & 0.14473 \\
\hline 22 & Decatur, IL & 89.90 & 595.00 & 0.04960 & 0.22085 & 0.13102 \\
\hline 23 & Rocky Mount, NC & 92.10 & 609.95 & -0.01067 & 0.22073 & 0.14035 \\
\hline 24 & Fargo, ND-MN & 92.40 & 627.17 & 0.01408 & 0.21853 & 0.14942 \\
\hline 25 & Madison, WI & 90.29 & 627.37 & 0.01994 & 0.21722 & 0.14405 \\
\hline 26 & Riverside-San Bernardino-Ontario, CA & 85.31 & 634.50 & -0.03564 & 0.21658 & 0.15349 \\
\hline 27 & Deltona-Daytona Beach-Ormond Beach, FL & 82.31 & 611.53 & -0.01252 & 0.21592 & 0.13423 \\
\hline 28 & Holland-Grand Haven, MI & 89.13 & 616.33 & 0.04038 & 0.21530 & 0.13030 \\
\hline 29 & Davenport-Moline-Rock Island, IA-IL & 90.24 & 609.85 & 0.03074 & 0.21444 & 0.13066 \\
\hline 30 & Orlando-Kissimmee, FL & 85.31 & 623.34 & 0.02140 & 0.21405 & 0.14107 \\
\hline 31 & Winston-Salem, NC & 89.97 & 610.21 & -0.03464 & 0.21357 & 0.13637 \\
\hline 32 & Chicago-Naperville-Joliet, IL (MSAD) & 86.14 & 623.68 & 0.06452 & 0.21321 & 0.14541 \\
\hline 33 & Wheeling, WV-OH & 88.04 & 616.50 & -0.03035 & 0.21288 & 0.12641 \\
\hline 34 & Palm Bay-Melbourne-Titusville, FL & 81.53 & 614.29 & -0.04858 & 0.21280 & 0.13375 \\
\hline 35 & Anchorage, AK & 84.99 & 615.02 & -0.03314 & 0.21260 & 0.13687 \\
\hline 36 & Bridgeport-Stamford-Norwalk, CT & 80.35 & 621.11 & 0.02178 & 0.21228 & 0.13969 \\
\hline 37 & Blacksburg-Christiansburg-Radford, VA & 84.72 & 609.12 & 0.04535 & 0.21085 & 0.12851 \\
\hline 38 & Boston-Quincy, MA (MSAD) & 82.15 & 623.61 & 0.00964 & 0.21069 & 0.14065 \\
\hline 39 & Savannah, GA & 85.90 & 606.89 & 0.04592 & 0.20971 & 0.12596 \\
\hline 40 & McAllen-Edinburg-Mission, TX & 87.02 & 612.19 & 0.00371 & 0.20939 & 0.12485 \\
\hline 41 & Parkersburg-Marietta-Vienna, WV-OH & 83.14 & 586.96 & -0.06511 & 0.20903 & 0.12054 \\
\hline 42 & Dothan, AL & 89.74 & 614.08 & 0.00209 & 0.20832 & 0.13010 \\
\hline 43 & New Orleans-Metairie-Kenner, LA & 84.05 & 607.50 & 0.03194 & 0.20829 & 0.12871 \\
\hline 44 & Tampa-St. Petersburg-Clearwater, FL & 83.95 & 615.48 & 0.03546 & 0.20826 & 0.13132 \\
\hline 45 & Bay City, MI & 91.20 & 621.44 & -0.01661 & 0.20815 & 0.13318 \\
\hline 46 & Jackson, MS & 88.06 & 602.27 & -0.00918 & 0.20720 & 0.12312 \\
\hline 47 & Salisbury, MD & 85.01 & 608.98 & -0.02165 & 0.20634 & 0.12784 \\
\hline 48 & Lafayette, LA & 87.98 & 612.22 & 0.02609 & 0.20574 & 0.12838 \\
\hline 49 & Racine, WI & 86.10 & 622.91 & -0.04241 & 0.20566 & 0.13952 \\
\hline 50 & Poughkeepsie-Newburgh-Middletown, NY & 83.72 & 616.17 & -0.00713 & 0.20500 & 0.12847 \\
\hline
\end{tabular}

Table 4 presents projections for the worst 50 MSAs ranked by projections of $d f w 60 p .^{13}$ The average projected default rates for these 50 are 0.222 for $d f w 60 p$ and 0.143

\footnotetext{
${ }^{13}$ The full list of projections is available from the author.
}

for $d f w 90 p$. Included with the default rate projections are the 2007 vintage wtd_ltv and wtd_fico as reported in the Loan Performance data and the projected housing price appreciation values. As a summary of these 50 MSAs, the 
average wtd_ltv and wtd_fico are 85.92 and 617.05 respectively. The loan-to-value ratio is considerably higher than the average for 2006 and 2007 reported vintages and the FICO score is below the 620 value usually considered the demarcation value between good and poor credit quality. The average projected housing price appreciation/depreciation rate for these 50 MSAs is -0.016, much less than the overall average for the 359 MSAs of 0.033. A review of the coefficient estimates in the 2006 vintage regressions for $d f w 60 p$, the housing price appreciation/depreciation projected changes appear to be driving the default projections.

The regional concentration of the 50 MSAs projected to have the greatest defaults, indicates that Florida MSAs lead with 12 of the 50 MSAs. Next worst is Michigan with 5, California and Illinois each with 4, Massachusetts is next with 3, and Louisiana, New York, North Carolina, North Dakota, West Virginia-Ohio and Wisconsin each have 2. It is note worthy that Florida is well in the lead and that California, long thought to be in nearly as serious default trouble, is a distant second. Also, of these 50, Las Vegas and San Diego, usually considered among the greatest risks, do not show up; they are down in rank at 112 and 100, respectively.

\section{Conclusions and Suggested Further Research}

The empirical estimates for the 2005 and 2006 vintages confirm that the important variables identified in the contingent claims models of debt value and default of Merton-Black-Cox, as summarized in the risk neutral default equation (6) are empirically important in explaining subprime loan default rates at the MSA level. Other loan level characteristics than leverage, wtd_ltv, and credit quality, wtd_fico, are important in conditioning the loan toward default such as ARM versus fixed rate and the lack of documentation on the borrower. It is our contention that the presence of documentation and whether the home is owner occupied are indicators of the level of psychic income from home ownership of the borrower and, thus, the willingness of the borrower to maintain payments on the mortgage even though the value of the underlying property is less than the amount of the mortgage owed.

The ability of the borrower to maintain payments depends on the borrower's earnings and employment. We include in the regressions certain economic characteristics of the MSA, the most important are the rate of housing price appreciation/depreciation, hpi_ratio, and the rate of employment growth, emp_ratio, of each of the 359 MSAs. The results prove interesting since employment growth is a statistically and economically important factor for the 2005 vintage loan defaults, but not for those originated in 2006, and the housing price appreciation/depreciation is statistically and economically important for the 2006 vintage defaults, but not for the 2005. This confirms our hypothesis that in periods of rising housing prices, as in 2005, loans made during such periods had a buffer of equity accumulating such that when housing prices did peak and begin declining, the borrower had an equity cushion to fall back on. As long as borrowers could make payments, they had a net positive net worth in the property. However, those mortgages originated in 2006 were made at a time when housing prices were peaking for many MSAs such that borrowers had little opportunity to accumulate equity from capital gains and found themselves with rising LTV based on current housing prices. Continually falling housing prices put pressure on these borrowers to discontinue or slow mortgage payments, thus increasing delinquency and default.

The projections for 2007 vintage defaults based on 2006 vintage estimated parameters bears out these findings. These results show that the housing price appreciation/depreciation rates are the main driver of MSA default rates. Of the 50 MSAs with the highest projected default rates for all of 2007, those in areas of declining housing prices are the ones with greatest projected default rates. The employment growth factor also conditions these rankings since it indicates the ability to make loan payments on time. Lower rates of employment growth also show up as meaningful. These results provide a picture of projected regional subprime mortgage defaults. As we show, Florida and California MSAs are most prevalent in the worst 50 MSAs by projected loan default.

This study has only scratched the surface of the research potential of the Loan Performance data. For example, this study could have been done by estimating the default likelihood of an MSA or region by using individual loans as observations and estimating default models by mortgage loan and then aggregating to any regional level desired. The economic variables would still be conditioning explanatory variables and they could be for MSAs, states or other regions. This approach would allow for a time seriescross-section model and be amenable to using a proportional hazards or survival analysis approach to estimating individual mortgage default rates. The author intends to undertake such research.

Another use of the Loan Performance data is to value securitizations of the subprime and prime loans. The data base is composed of data on individual loans that are in pools of securitizations. The valuation of a securitization pool of subprime mortgages, and any of the tranches derived from it, depends on the underlying value of the component mortgages. Measuring the interest sensitivity of the value from prepayments and default rates simultaneously, will get better current valuations of the pool and tranches. The projection of securitization value can be useful in isolating the effect of economic factors of regions on the valuation of the securitization and effect on banks holding these pools or tranches. As in the model presented in this paper and the ones proposed above, the contingent claims approach to valuing debt and value simultaneously is the conceptual foundation to developing the empirical models.

\section{References}

[1] Bangia, A. Diebold, F.X., Kronimus, A., Schagen, C., and Schuermann, T. (2002). "Ratings Migration and the Business Cycle with Application to Credit Portfolio Stress Testing”. Journal of Banking and Finance 26, 445-474.

[2] Bartlett, William W. (1994). The Valuation of Mortgage-Backed Securities, Irwin Professional Publishing, Burr Ridge, IL, p. 471482.

[3] Bernanke, B. (2007). "Housing, Housing Finance, and Monetary Policy," Speech, Federal Reserve Bank of Kansas City's Economic Symposium, August 31, 2007. 
[4] Black, F. and J. Cox. (1973). "Valuing Corporate Securities: Some Effects of Bond Indentures”. Journal of Finance 31(May) p. 135167.

[5] Campbell, J. Y., and J. F. Cocco (2003). "Household Risk Management and Optimal Mortgage Choice," Quarterly Journal of Economics, 118(4), 1449-1494.

[6] Cutts, A. C., and R. A. van Order (2005). "On the Economics of Subprime Lending," The Journal of Real Estate Finance and Economics, 30(2), 167-196.

[7] Demyanyk, Y and O. Van Hemert (2007). "Understanding the Subprime Mortgage Crisis,” Working Paper, Federal Reserve Bank of St. Louis, St. Louis, MO (October).

[8] Deng, Y., J. M. Quigley, and R. A. Van Order (2000). "Mortgage Terminations, Heterogeneity and the Exercise of Mortgage Options," Econometrica, 68(2), 275-308.

[9] Fama, E. (1986). "Term Premiums and Default Premiums in Money Markets”. Journal of Financial Economics Vol.17, No. 1. 175-196.

[10] Giliberto, S. Michael and David C. Ling (1992). "An Empirical Investigation of the Contingent- Claims Approach to Pricing Residential Mortgage Debt, Journal of the American Real Estate and Urban Economic Association, 20, p. 393-426.

[11] Hanweck, Gerald A, (1971), An Empirical Study Commercial Bank Pricing Behavior in Business Lending, Ph.D. dissertation, Washington University in St. Louis, Department of Economics, St. Louis, MO.

[12] Hanweck, Gerald A.(2001). “A Methodology for Using Market Information to Assess Banking Company Insolvency Risk: The Simultaneous Use of Subordinated Debt and Market Values", Working Paper, FDIC, October 2001.

[13] Hanweck, Gerald A. and Louis Spellman (2002). "Forbearance Expectations and the Subordinated Debt Signal of Bank Insolvency", presented at the joint FDIC and Journal of Financial
Services Research Conference on "Pricing the Risks of Deposit Insurance”. (September) 2002, FDIC, Washington, DC.

[14] Hendershott, Patric H. and Robert Van Order (1987). "Pricing Mortgages: An Interpretation of the Models and Results," Journal of Financial Services Research 1, 77-111.

[15] Hull, John C. (2000), Options, Futures and Other Derivatives, Prentice Hall, Inc., Upper Saddle River, NJ.

[16] Hull, John C. (2007), Risk Management and Financial Institutions, Pearson Education, Inc., Upper Saddle River, NJ.

[17] Koijen, R., O. Van Hemert, and S. Van Nieuwerburgh (2007) "Mortgage Timing," Working paper, New York University.

[18] Koopman, S.J. and A. Lucas, (2003). "A Survey of Cyclical Affects in Credit Risk Measurement Models." Tinbergen Institute Discussion Paper, TI 2003 - 062/2, July.

[19] Koopman, S.J. and A. Lucas, (2003). "Business and Default Cycles for Credit Risk." Tinbergen Institute Discussion Paper, TI $2003-062 / 2$.

[20] “TrueStandings Securities: Attributes Metrics and Filters,” (2005). Loan Performance, 188 The Embarcadero, San Francisco, CA.

[21] Merton, Robert C., (1974), "On the Pricing of Corporate Debt: The Risk Structure of Interest Rates." Journal of Finance 29 (May), 449-470.

[22] Pennington-Cross, A., and S. Chomsisengphet (2007). "Subprime Refinancing: Equity Extraction and Mortgage Termination," Real Estate Economics, 35(2), 233-263.

[23] Titman, Sheridan and Walter Torous, (1989). "Valuing Commercial Mortgages: An Empirical Examination of the Contingent Claims Approach to Pricing Risky Debt,” Journal of Finance, 44, p.345-373.

[24] Van Hemert, O. (2007). "Household Interest Rate Risk Management," Working paper, New York University.

[25] von Furstenberg, and R. J. Green (1974). "Home Mortgage Delinquencies: A Cohort Analysis," Journal of Finance, 29(5), 1545-1548. 